\title{
ON WRITING FLUID HISTORIES OF MODERN ART WITH JACQUES RANCIÈRE
}

\author{
KAROLINA RYBAČIAUSKAITE் \\ Institute of Philosophy, Vilnius University \\ karolina.rybaciauskaite@fsf.vu.It
}

\begin{abstract}
In this paper it is claimed that the conception of art regimes by Jacques Rancière may be a productive tool for coming across various binary oppositions used while thinking about modern art, such as modernism/social realism, official/non-official, political/apolitical, and let us write more fluid histories of modern art in the post-socialist and post-soviet countries.
\end{abstract}

Keywords: Clement Greenberg - binary oppositions - fluid histories - modern art - art regimes - Jacques Rancière - post-socialist

It is common to think in the discourse of Western history and theory of art that the first glimpses of modernity in the field of art manifested themselves as the abandonment of the mimesis principle and the implementation of the idea of autonomy. Based on this, it is claimed a certain evolution of art during which figurative art began mutating into abstract art - this way a significant step was taken from realism to modernism. When the fall of this evolutionary logic soon is implied, terms as "avant-garde", "post-modernity", as well as "art crisis", "death" or "end", are to be used. One of the critics of theological understanding of modernity, French philosopher Jacques Rancière, claims that these terms interfere with the ability to understand the real changes brought by modernity. He suggests a concept of art regimes which fundamentally breaks with the conventional periodization of modern and contemporary art and offers an alternative to many theoretical attempts to rethink the developments of art in 19th and 20th centuries (i.e. by Clement Greenberg, Jean-François Lyotard, Fredric Jameson, Jean Baudrillard, Arthur Danto and others ${ }^{1}$ ).

Rancière himself occasionally refers to "Western tradition" in his texts, but it is not entirely clear to what extent his regimes of art are specific to the particular geographical or cultural region. ${ }^{2}$ In this work it is assumed that although Rancière himself never refers to Central and Eastern European art in his texts, the theory of artistic regimes

1 For more, see Joseph J. Tanke, What Is the Aesthetic Regime? In: Parrhesia, No. 12, 2011, pp. 71-81.

2 Gabriel Rockhill, Interventions in Contemporary Thought: History, Politics, Aesthetics, Edinburgh 2017, p. 207. 
is equally applicable in this region. ${ }^{3}$ Moreover, the aim of this paper is to demonstrate how Rancière's critique to Greenberg's assumptions and his own theory of art regimes may let us break away from various binary oppositions tightly twined around the discourse of history and theory of art, often used while thinking about modern art in the Central and Eastern Europe, such as modernism/social realism, official/non-official, political/apolitical. In the first and second part I am discussing the theoretical premises which may imply the different narratives of modern art and in the last part it is going to be shown how those ideas could operate in the context of modern art in Central and Eastern Europe. ${ }^{4}$

\section{From Reserved Pictorial Flatness to the Sphere of Common Surface}

One of the main reasons that allow us to think that modern art forms are universal par excellence and that its evolution should not only carry on there where it began, but also in other places - it is an idea that in the modern times art as such started to become autonomous and its main mission was to prove so. According to Greenberg, only in this way art field could maintain its elitism and would not become part of commercial culture. He stated that each branch of art should express its autonomy in its own way - showing not what could be valuable in art in general, but what is unique, non-reductive and impossible to reach when being dedicated to other activities in any of these art branches. For instance, in the case of modern painting, it turned to abstract because there was a vital necessity to get away from three-dimensionality, a unique property of sculpture. It was able to take the spectator to "a strictly pictorial, a strictly optical third dimension" and bring up "optical sensations". 5

Rancière denies Greenberg's idea of artistic autonomy and the pursuit of purity in the various branches of art. He claims the "flat surface paradigm" perfectly served to construct an ideal history of modernity, but in fact, such an ideal artistic autonomy never existed; therefore, it could not stop being affected by various "negative side-effects". As he states himself: "Perhaps we would escape these scenarios of diabolical perversion if we understood that the lost paradise never in fact existed. Pictorial flatness was never synonymous with the autonomy of art. The flat surface was always a surface of communication where words and images slid into one another." 6 In Rancière's understanding, if mimesis meant a certain set of rules which could create connections between laws of poiesis and the forms of aisthesis, aesthetics resulted in a truly absence of any rule of sensorial con-

3 It should be noted that Rancière's regimes of art are not intrinsically dependent on genres or creative strategies inherent in the histories of art. They describe the nature of systems of production and perception of artistic creation and ways in which the relationships between artistic creation and aesthetic experience are distributed, so it operates within various types of creative activity across different times.

4 This work is partly based on my Master thesis' research at Vilnius University 'Jacques Rancière's Conception of Art Regimes in the Context of Art History of the Post-Soviet Countries', (2016-2018). I am grateful for valuable and generous comments from my supervisor prof. dr. Kristupas Sabolius.

5 Clement Greenberg, Modernist Painting, first published in: Forum Lecture, Washington, DC, 1960, then reprinted in: Art \& Literature, No. 4, Spring 1965, pp. 193-201.

6 Jacques Rancière, The Future of Image, trans. by Gregory Elliot, Brooklyn and London 2007, p. 104. 
nection between artistic production and artistic experience. This way Rancière claims an aesthetic regime of art that mostly revealed itself during the aesthetic revolution at the second half of 18th century in opposition with representative regime of art.

Ethos, poiesis/mimesis and aisthesis are the keywords through which Rancière defines the production and perception of artistic creation. Based on them, he distinguishes three regimes of art which in terms of history of formation at first sight seem to have a lot in common with Western history of art, but in fact, they do not match up to specific historical stages. ${ }^{7}$ In the first, ethical regime of art, images are used to serve communal purposes and their ability to positively affect ethos. The second regime of art is mimetic regime of art because during its operational time creative activity and methods are classified and a new hierarchical "arts" system is identified. This regime is called "the representative regime" because it is where the concept of representation or mimesis connects the earlier mentioned ways of making, as well as serves the idea of a hierarchical community. The aesthetic regime of art asserts the absolute singularity of art and, at the same time, destroys any pragmatic criteria for isolating this singularity. ${ }^{8}$ For Rancière it is not a matter of simple "perception," but rather a matter of "fabric of sensible experience" by which the artworks are created. This material is made up from concrete institutions: places where expositions and performances are held, ways of circulation and reproduction, as well as forms of perceptions and attachments, concepts, narratives, and evaluations that identify and give meaning to those "art" pieces. ${ }^{9}$

In his theory of art regimes, Rancière opposes Greenberg and states that a modern switch from realistic to abstract depiction or the "anti-mimetic revolution" never meant the renunciation of resemblance, because mimesis is not based on resemblance, but rather on certain connections between artistic practices and the distribution of their visibility and perception. It is not based on refrain "each to his own" binding separate art types and medias characteristic only to them. To the contrary, the principle is "each to everyone else's". Poetry does not aim to imitating itself, but both poetry and painting do imitate and at the same time maintain a certain distance from each other. This doesn't mean that verbal art only dwells in the textual and visual art - only in the graphic features. On the contrary - this proves that the principle separating "verbal" and "form" as well as temporal and dimensional art vanishes, and individual imitation spheres become replaced by the sphere of common surface. ${ }^{10}$ This sphere it is the actual medium of modern painting - a medium that should not be confused with art means or any other kind of restrictive norms. ${ }^{11}$ Therefore, according to Rancière, art's singularity affirmed by the aesthetic regime of art became evident not only by its separation as a unique sen-

\footnotetext{
7 The term régime defines an operative system's type, rather than the conditions of time or space.

8 Jacques Rancière, Le Partage du Sensible: Esthétique et Politique, Paris 2000, pp. 31-32.

9 As noted by Ben Highmore, the term of modernism that usually gives privilege to non-mimetic visual art practices, in Rancière's theory, becomes defunct. The only way that abstraction as such could emerge, was by breaking the distribution of sensible by something far more fundamental - first of all, the question of the painting's subject should lose meaning, so that certain subjects and pieces that represent them would become equally important (Ben Highmore, Ordinary Lives. Studies in the Everyday, Oxon \& New York 2011, p. 49).

10 Rancière (note 6), pp. 104-105.

11 Ibid, p. 87.
} 
sual sphere, but also as the creation of typical forms in a common form-symbol surface sphere, and as such being inherently political. ${ }^{12}$

\section{From the Continuity of Authentic Modernism to the Heterogenic Modernities}

Another common assumption for writing histories of modern art denied in Rancière's philosophy of art is that of progressive evolution of art characteristic to Western thought. The idea of continuity in modernity is linked with the search for an authentic historical and cultural development exclusively common to Western civilization which in Greenberg's theory becomes the main motive to separate "high" culture from "low" culture, "avant-garde" from "kitsch" and the Western world from Soviet Russia. According to his logic, avant-garde art that demonstrated a self-reflective tendency of Western culture had to retreat and make place for the academism and commercialism, and for the kitsch that came from it: popular, commercial art and literature. ${ }^{13}$ Thus, Greenberg claims that avant-garde art always belonged to the minority: a small group of the most powerful and educated people, whereas kitsch, folk art or the official culture in Soviet Russia was the art of the illiterate, poor and meant to the masses. By stating that that in Soviet Russia the dominating culture was industrial and official, therefore - kitsch, he also states its shoddiness, an irreplaceable lack of modernist authenticity.

Rancière, on the other hand, do not object that modern art is closely connected to the past, but he also states that the aesthetic art regime does not oppose old with new, but rather creates a contrast between two "historical regimes". In other words, the aesthetic regime of art works not as means to initiate a breakthrough in the field of art, but rather to reflect on how art is created and what does it create, and based on what was art before, it seeks to create new forms of life - i.e. what would art be and what would have art been. ${ }^{14}$ To illustrate this principle, Rancière uses the example of futurists and constructivists. By declaring the end of art and perceiving their creative practices as something what constructs, decorates or gives time and space a certain rhythm of communal life, they compared the end and identification of art with the life of community. Even though they invented new art styles, they did not strive for an artistic revolution - they only wanted to suggest a new way to live among words, images, and goods. ${ }^{15}$

Rancière, in contrast, claims that the advocates of historical modernism distinguishes far too sharp differences in a complex configuration of the aesthetic regime of art and despite their wish to turn their modernism into the only possible reason and direction of history, the temporality common to the aesthetic art regime is a coexistence of a few

12 The principle of distribution of sensible (partage du sensible) is at the heart of politics and at the same time is inherent in aesthetics, thus on a metalevel aesthetics is inseparable from politics. That means that a variety of practices and knowledges demonstrating what has been hitherto invisible, unheard, and incomprehensible, create a common world, and at the same time determine the ability of subjects to be and act in, perceive, understand, and transform certain parts of the world (Jacques Rancière, Modern Times: Essays on Temporality in Art and Politics, Zagreb 2017, p. 12).

13 Clement Greenberg, Avant-garde and Kitsch, in: Art and Culture: Critical Essays, Boston 1965, p. 9.

14 Rancière (note 8), p. 36.

15 Ibid, pp. 36-37. 
heterogenic temporalities. ${ }^{16}$ Respectively, modernity does not led by the principle of acceleration, but it is made up of "écarts" - a set of heterogenic modernities. ${ }^{17}$ Therefore, Rancière does not deny modern art's link to the past, but rather states its complexity. In his theory of art regimes, "high" and "low" culture, "avant-garde" and "kitsch", modernisms in West and Soviet Russia are linked by artists' common need and wish to create a sensible fabric of common life.

\section{Three Regimes of Art at Once: Typical Forms and the Fabric of Sensible}

Rancière takes the transition from realistic to abstract art that took place in the turn of the 20th century not as a continuous prosperity of formalistic improvement of art and optical senses, but rather as a result of operation of heterogenic aesthetic regime of art and expression of new sensible structures in a common sphere of typical forms. Because of that, when writing histories of modern art based on Rancière's understanding of changes in the regimes of art, we do not need to compare the primary, original, and therefore the best sequence that occurred in the history of Western European and American art with all other, secondary, allegedly analogue, or due to whatever outside factors lacking certain components sequences from Central and Eastern Europe or elsewhere.

In fact, the concept of teleologic modernity is very problematic when telling the histories of modern and contemporary art created in the post-socialist countries. According to Croatian art historian and philosopher Ana Peraica, Greenberg's widely accepted and used colonialist understanding of modernity in which the (neo)avant-garde art aimed against mass culture defining 'high' Western culture is put in contrast with 'low' culture and its supposedly 'authentic' Eastern Europe product - social realism, works as a means to create a narrative based on shame and lack of self-worth. ${ }^{18}$ For instance, in the Lithuanian context, histories of modern and contemporary art from early 1960s to late 1980s are still being narrated as late and silent modernisms implying the belatedness and disability of artists and their artworks at that time. ${ }^{19}$ Respectively, when telling the histories of modern art in the post-socialist countries, not only formal criteria should be taken into consideration, but also the questions of content - especially, when it concerns the concrete cultural account. This aspect is specifically important if we keep in mind that cultural politics were different across the countries in Central and Eastern Europe, thus the development of formal features could be different, but questions which were addressed might be similar, or vice versus.

16 Ibid, p. 38.

17 Jacques Rancière, Understanding Modernism, Reconfiguring Disciplinarity: Interview with Jacques Rancière (May 11, 2015), in: Patrick M. Bray (ed.) Understanding Rancière, Understanding Modernism, London-New York, 2017, p. 265.

18 Ana Peraica, A Corruption of 'Grand Narrative' of Art, in: IRWIN (eds.) East Art Map: Contemporary Art and Eastern Europe, London 2006, p. 473.

19 More about the case of Lithuanian modernisms and the possibility to employ Jacques Rancière's theory of art regimes in Lithuanian modern art histories as using the practical example of artworks by Lithuanian artist Vincas Kisarauskas, see Karolina Rybačiauskaite, Rancière's Challenge for the Lithuanian Modern Art Histories: The Possibility of New Sensible Structures, in: Problemos, vol. 97, 2020, pp. 198-208. 
Ultimately, Rancière could give us a way, according to which, modern art created in Eastern and Central Europe can be evaluated not as lingering between modernism and social realism or just being a belated copy of Western modernism, but it could be perceived as timely operating within all three regimes of art: the ethical, the representative and the aesthetic. On one hand, part of it was created and evaluated throughout its educational effect on society, without dismissing the requirements of the mimesis principle when having in mind artistic value and differences from Western modernism. ${ }^{20}$ On the other hand, part of the artists of so called official and unofficial art - both were keen on searching for new typical forms and seeking to create a new sensible fabric of a common life which on the level of metapolitics was promising one or another structure of future society. It manifested itself through the internal structures of artworks and various intermedial connections - when what was invisible, inaudible, and incomprehensible became visible, audible, and enabled to broaden the limits of intelligibility.

To conclude, we could say that Rancière's concept of regimes of art allows us to talk about the modern forms and contents across at least a few different regions with different political, social, cultural contexts. While offering a conceptual way to perceive modern art in the post-socialist countries, as operating within the three regimes of art simultaneously, it may help to overcome such binary oppositions as modernism/social realism, official/non-official, political/apolitical. I believe that the ability to perceive this region's modern art as being very rich of innovative structures of sensible fabric, could open the possibility for more affirmative interpretations and histories of art.

\section{SUMMARY}

In this paper it is claimed that if we want to come across such binary oppositions as modernism/social realism, official/non-official, political/apolitical, often used while thinking about modern art in the post-socialist and post-soviet countries, we need to re-think the theoretical premises of artistic modernism more radically. By analysing Rancière's theory and his critique to Clement Greenberg's assumptions, it is demonstrated that if we would think about the modern art of 20th century not as an autonomous space, which needed to prove itself within the development of history or the external social and political effects, but as the intersection of all three regimes by Rancière, we may be able to write more fluid histories of modern art. In the space of searching for the new typical forms and creating the sensible fabric of common life, it is possible to think about the artistic forms and contents across the different regions.

20 As Slovenian art historian Eda Čufer notices: 'Over time, the monopoly of the unions was not based on the idea of maintaining Social Realism as the one legitimate style, as on the principle of maintaining control over definition of art. In countries like Poland, Czechoslovakia or Yugoslavia, Unions of Visual Artists tolerated or even propagated rigid versions of Greenbergian modernism while remaining intolerant of any approach to art other than the one they prescribed.' See Eda Čufer, Enjoy me, Abuse me, I Am Your Artist: Cultural Politics, Their Monuments, Their Ruins, in: N. Kotsopoulos (ed.) Contemporary Art in Eastern Europe, London 2010, pp. 195). 


\section{SELECTED BIBLIOGRAPHY}

Eda Čufer, Enjoy me, Abuse me, I Am Your Artist: Cultural Politics, Their Monuments, Their Ruins, in: N. Kotsopoulos (ed.), Contemporary Art in Eastern Europe, London 2010.

Clement Greenberg, Modernist Painting, first published in: Forum Lecture, Washington, DC, 1960, then reprinted in: Art \& Literature, Lugano, No. 4, Spring 1965, pp. 193-201.

Clement Greenberg, Avant-garde and Kitsch, in: Art and Culture: Critical Essays, Boston 1965, pp. 3-21.

Ben Highmore, Ordinary Lives. Studies in the Everyday, Oxon \& New York 2011.

Ana Peraica, A Corruption of 'Grand Narrative' of Art, in: IRWIN (eds), East Art Map: Contemporary Art and Eastern Europe, London 2006.

Jacques Rancière, Le Partage du Sensible: Esthétique et Politique, Paris 2000.

Jacques Rancière, The Future of Image, trans. by Gregory Elliot, Brooklyn and London 2007.

Jacques Rancière, Modern Times: Essays on Temporality in Art and Politics, Zagreb 2017.

Jacques Rancière, Understanding Modernism, Reconfiguring Disciplinarity: Interview with Jacques Rancière (May 11, 2015), in: Patrick M. Bray (ed.) Understanding Rancière, Understanding Modernism, London-New York, 2017, pp. 263-289.

Gabriel Rockhill, Interventions in Contemporary Thought: History, Politics, Aesthetics, Edinburgh 2017.

Karolina Rybačiauskaitè, Rancière's Challenge for the Lithuanian Modern Art Histories: The Possibility of New Sensible Structures, in: Problemos, vol. 97, 2020, pp. 198-208.

Joseph J. Tanke, What Is the Aesthetic Regime? In: Parrhesia, No. 12, 2011, pp. 71-81. 